\title{
TYPES OF DOMESTIC VIOLENCE EXPERIENCED BY WOMEN IN ABUSIVE RELATIONSHIPS
}

\section{Ilze Slabbert, Sulina Green}

\section{INTRODUCTION}

Research and specialised practice indicate that women who are abused by their intimate partners are at an increasing risk the longer the abuse continues. Many men show escalating violent behaviour toward their female partners and many women are killed by their partners (Roche, 1999:24). Several researchers (Artz, 1999:2; Damon, 2003:94; Flinck, Paavilainen \& Asredt-Kurki, 2005:383; Gelles, 1999:168; Vincent \& Jouriles, 2002:7) view domestic violence as a leading cause of female injury in almost every country. Dwyer, Smokowski, Bricout and Wodarski (1995:185) claim that injuries as a result of domestic violence are more common than from muggings, car accidents and death resulting from cancer combined.

Domestic violence is a serious social challenge that social workers have to deal with on a daily basis. It is estimated that between $40 \%$ and $70 \%$ of all murder victims in South Africa are killed by their intimate partners, usually after a long history of domestic violence (Carstens, 2007:14). The Annual Report of the South African Police Service (SAPS) for 2004-2005 indicated that women and children accounted for $100 \%$ of rape victims, $83.3 \%$ of indecent assault cases, $64.2 \%$ of common assault victims and $59 \%$ of contact crime. These types of abuse mostly occur in the home, which is supposed to be a safe shelter for women and children (Carlson, 1991:471; Griggs, Morris \& Ehlers, 2005:1). It is no cause for wonder that researchers like Danis and Lee (2003:237), Stephens and McDonald (2002:81) and Sullivan and Hagen (2005:346) claim that the home can be one of society's most dangerous places when violence occurs in intimate relationships.

It is evident from the literature (Callaghan, 1995; Harrison, 1998; Makofane, 2002; Nordien, 2003) that a number of battered women are unable to escape from their situation, but still cope. Consequently, the aim of the study was to investigate how women in abusive relationships experience the different types of domestic violence.

\section{RESEARCH DESIGN AND METHOD}

A qualitative study with a phenomenological approach was proposed. A phenomenological approach is described as research in which the researcher identifies the "essence" of human experiences concerning a phenomenon, as described by participants in a study (Cresswell, 2003:15). It is a study that describes the meaning of the experience of a phenomenon (in this case domestic violence) by various individuals (in this case women) (Fouché \& Schurink, cited in De Vos et al., 2011:316). Henning (2004:3) elaborates that, in qualitative, as in quantitative research, the researcher wants to know what happens, how it happens and why it happens. In qualitative research however, it is not only the actions, such as speech and writing of human beings that are important, but also their feelings and thoughts. 
Two non-governmental organisations (NGOs) and one psychologist were approached to obtain the sample of 20. Purposive sampling and snowball sampling were used in this study. Purposive sampling is the procedure the researcher chooses the participants. Selection of participants is based mainly on their knowledge, experience of and role in the phenomenon to be researched. There are no set rules about the sample size in a qualitative study, but smaller sample sizes are usually used (Whittaker, 2009:34).

Snowball sampling was also used, because the NGOs could not identify enough participants and saturation was not reached. In snowball sampling the researcher collects data on a few participants and these persons refer him to other participants. Four participants were identified in this way (Strydom \& Delport, cited in De Vos et al., 2011:390).

The sample was drawn from a population that had to meet the following criteria for inclusion:

- They had to be female, between the ages of 22 and 60 .

- They had to be in an abusive relationship at the time of the study, or had to have been in an abusive relationship fewer than six months previously.

- They had to be residing in or around Cape Town.

- They had to have received professional help from a social worker, psychologist or nursing sister during the preceding six months, or still be receiving such help.

The study utilised an exploratory and descriptive design such as described by Fouché and De Vos (2011:95). Exploratory studies aim to gain insight into a situation, phenomenon or person(s). In this study, insight was gained into domestic violence. A "thick description" of the data of the interviews was obtained, and in this regard the study can also be viewed as descriptive.

\section{DISCUSSION OF THE FINDINGS}

The profile of the participants and their experience of domestic violence are subsequently presented.

\section{Profile of participants}

The age of the sample of twenty women varied between 23 and 49. Researchers such as Amoakohene (2004:23), Fleury-Steiner, Bybee, Sullivan, Belknap and Melton (2006:327) and Jewkes, Levin and Penn-Kekana (2002:1603) indicate that women of child-bearing age are much more vulnerable to domestic violence than women whose children are independent, as the need to provide for their children creates extra pressure. While authors such as Danis and Lee (2003:28) argue that women of all ages and circumstances are exposed to intimate partner violence, not only those who still have children in the home, it is significant that nineteen (95\%) of the participants still had to care for dependent children in their homes.

Nine of the twenty participants (45\%) were married. Five of the participants $(25 \%)$ were cohabiting. Six of the participants $(30 \%)$ were separated from their partners at the time the interviews were conducted. The decision to leave their partners was not easy as 
all of them faced huge financial challenges. Only two of the six participants who were separated from their partners seemed adamant never to return. The main concern of those who were determined not to return was that they would have to look for other work in order to survive financially and they had difficulty in finding affordable accommodation. This echoes findings by researchers such as Artz (1999:3), Ferrato (2000:10), Danis and Lockheart (2004:15) and Vincent and Jouriles (2002:78), who state that women who plan to leave their partners face several serious challenges, such as accommodation, raising of children, making it on your own and other practical matters. According to the literature, no significant associations were found between domestic violence and marital status (Jewkes et al., 2002:1603-1617).

All the participants still had children in the home, except for one whose children had grown up. Women who still have children to care for are in a much more difficult position when it comes to leaving a partner than those whose children are not around any more. A significant number of women who are abused have children, who therefore are also exposed to violent behaviour that has a devastating effect on them. Suspicion and fear are common among children who have lived in violent homes (Ferrato, 2000:53). What makes domestic violence a distinct type of trauma, is that the perpetrator lives in the same house as the child and often is the child's father. Children exposed to this type of violence often have feelings of betrayal. Their perceptions of home and safety are seriously marred. Children exposed to domestic violence are at increased risk of multiple behavioural and emotional difficulties that manifest in low self-esteem, anxiety attacks, displaying aggressive behaviour, withdrawal and thoughts of suicide (Danis \& Lockheart, 2004:34).

The educational level of the participants was also noted. It is significant that none of the participants had post-matric education. Only four participants (20\%) completed Grade 12. Six participants had an educational level of Grade 9 or 10. Two of the participants $(10 \%)$ had completed Grade 8 . Six participants $(30 \%)$ had a primary school education varying from Grade 4 to Grade 7 . Two participants (10\%) were illiterate. This correlates with research conducted by Parenzee and Smythe (2003:48, 49), who found that the relationship between income and low education levels is significant. Abused low-income women usually have low levels of education, reducing the possibility of alternative employment and reinforcing the poverty.

\section{The types of domestic violence}

The criteria for inclusion in the study required that participants in this study had to be in a physically abusive relationship or had to have been in such a relationship during the six months prior to the study, as mentioned earlier. The range of abuses that women may suffer is wide and can include physical, sexual, psychological and economic abuse, as well as stalking, forced isolation in the home and other controlling behaviours (Bollen, Artz, Vetten \& Louw, 1999:7; Domestic Violence Act, No. 116 of 1998). According to several authors, such as Bassuk, Dawson and Huntington (2005:33), Danis and Lee (2003:28) and Riger, Bennet, Wasco, Schewe, Frohmann, Camacho and Campbell 
(2002:15), domestic violence generally occurs in the form of the following types of abuse: physical, emotional, sexual and economic.

These four types of domestic violence experienced by women are discussed in the following sections.

\section{- Physical abuse}

Physical abuse can either be controlled or impulsive and consists of physical assaults. These assaults result in injuries ranging from bruising, scalding, burning and stabbing to internal injuries, cracked ribs or broken bones. Persistent blows to the head may cause serious head injuries that often go undetected and untreated. Some abusers will make sure that they inflict the physical injury to parts of the body not normally seen, such as the torso, rather than risk leaving marks on the face or limbs (Makofane, 2002:86).

Another kind of physical abuse leaves no physical evidence, as when a head is forced into the toilet, or ice cold baths and locking up is used. Physical neglect, such as withholding or eliminating food, shelter and clothing may also form part of physical abuse. Physical abuse includes throwing things, kicking, slapping hitting, pushing, shoving, grabbing, choking, strangling and inflicting head injuries, to name but a few. Death resulting from physical injuries is the horrible outcome for some women who are in an abusive relationship (Sanderson, 2008:23).

The most obvious and serious consequence of intimate violence toward women is the personal suffering it causes and the long-term toll it takes on women and their children, as can be seen from the following excerpts.

"Sometimes if I am asleep, he will throw water over me that I am drenched."

"He would beat me severely, so that my eyes were blue. I also had bruises on my body. I was pregnant with her, and then he would also beat me. The last time he beat me was with a thick stick on my ankle. I could not walk for three days. I could not go to work."

"He kicked and beat me regularly. He shoved my head in the toilet."

"People did not realise how intensely I experienced this and through what emotions I had to struggle. He would beat me if I ever tried to say how I felt. I did not have anywhere to go. You can only stay two or three days with a pal and then you must go back to the mess with all your emotions."

It is significant that some participants indicated types of physical abuse other than the "normal" physical abuse such as kicking and hitting, as can be seen from the experiences of two participants. All these insulting actions by perpetrators boil down to keeping "their women" under control. This is revealed in the literature by a whole range of humiliating acts against women such as pushing, slapping, belittling, burning, strangling and tying up that can all be classified under physical abuse (Domestic Violence Act, No. 116 of 1998; Romito, 2008:17).

Most of the participants in this study indicated that their children were present while they were physically abused. This is supported by Bollen et al. (1999:25), who reported 
that $98 \%$ of the 269 women they had interviewed indicated that their children were present while they were being abused.

Stephens and McDonald (2002:80) indicate that some women in violent homes are exposed to severe physical violence, sometimes referred to as "patriarchal terrorism", with abuse happening on a regular basis, even up to 60 times annually. Weapons such as knives and guns may also be used. At least five of the twenty participants $(25 \%)$ in this study indicated that they were exposed to "patriarchal terrorism" and were physically abused at least once (at times up to three times) a week. They also had physical scars on their bodies and faces caused by stabbing and being hit with an object ("See how I look ... these are wounds where he stabbed me..."). Their exposure to violence would range from being kicked, being hit with a fist, suffering cracked ribs, being hit with an object, being threatened with a weapon to being stabbed. These five participants $(25 \%)$ had to be hospitalised at some or other stage as a result of wounds resulting from the violence.

All the participants indicated that they were exposed to "lesser" types of violence, such as hitting and kicking. Stephens and McDonald (2002:80) refer to this as "ordinary" or "everyday" domestic violence in which conflict often gets out of hand. These "milder" types of physical violence should be of as much concern as more serious types of physical abuse, because all types of physical abuse are problematic. Milder types of abuse in some cases also give rise to more extreme acts of aggression. Several scholars (Browne \& Herbert, 1997:63; Ferrato, 2000:41; Hampton, Vandergriff-Avery \& Kim, 1999:39; Purvin, 2007:188) observe that women and children are more vulnerable than men in inter-partner violence. In the long run, domestic violence takes its toll on the whole family and the family discord has serious emotional implications, as can be seen from quoted experience ("People did not realise how intensely I experienced this and through what emotions I had to struggle"). As Bollen et al. (1999:7) rightly stated: "The results of domestic violence are severe, the trauma lifelong."

\section{- Emotional abuse}

Emotional abuse can be verbal or non-verbal. It is persistent and corrosive, destroying self-worth and self-esteem. This type of abuse usually includes the use of ridicule, insults, accusations, infidelity and ignoring one's partner, all of which result in the breaking down of the victim's self-esteem and self-worth. Emotional abuse can also occur when the perpetrator places his partner in a position in which she has to gain his favour through her compliant behaviour, like a young child who has misbehaved. Deliberate isolation from family, friends and neighbours is another type of emotional abuse (Sanderson, 2008:23; Wiehe, 1998:6). Authors such as Browne and Herbert (1997:83), Romito (2008:17) and Sanderson (2008:23) are of the opinion that emotional abuse is more frequent than physical abuse and more difficult to detect. These two types of violence are equally destructive. How participants experienced emotional abuse is discussed below.

"And then there is the verbal abuse. I do not mind all the physical stuff, but the words ... they hurt the most. Your bruises disappear, but the words ...they remain." 
"He beats me, but the worst is the verbal abuse. He calls me all kinds of horrible names... and in front of the children."

"Yes, I have often been beaten and kicked. That is why I left. He also called me names.

"He has two children with another girl. It is hard for me that he had these children, while he was still with me."

Each of the 20 participants experienced emotional abuse, together with the physical abuse. Emotional abuse varied between insults, shouting, name calling, and belittling in front of children or other people (Domestic Violence Act, No. 116 of 1998). As can be seen from one participant's response ("but the worst is the verbal abuse..."), the emotional abuse was often experiences as worse than the physical abuse. Most of the participants indicated that the emotional wounds were deeper and more painful than the physical wounds. This correlates with Walker's (1984) view, which describes emotional trauma as characterised by degradation and humiliation, which is the most painful form of abuse women suffer.

Authors such as Enosh and Buchbinder (2005:9), Ludsin and Vetten (2005:18), Pineless, Mineka and Zinbarg (2008:166) and Vincent and Jouriles (2002:8) state that physical abuse is almost always accompanied by some form of emotional abuse. Women who have experienced domestic violence therefore have frequently received negative feedback from their partners about different aspects of their character, aptitude, attractiveness, and personality. They may furthermore internalise their partners' negative views of them and blame themselves for their partners' abusive actions. Bollen et al. (1999:7) have noted that psychological abuse often occurs more frequently and chronically than physical violence and the well-being of many women is affected negatively by psychological abuse. This correlates with the experience of one of the participants: "Your bruises disappear, but the words ... they remain."

It is significant that eight of the participants (40\%) were affected by unfaithfulness on the part of their partners. Unfaithfulness is seen by several authors such as Artz (1999:12), Makofane (2002:84) and Ruiz-Perez and Mata-Pariente (2006:1156), as part of emotional abuse. The unfaithfulness varied from having a one-off sexual relationship with another woman, to having several girlfriends, to having children with other women. The participants whose partners were unfaithful struggled to come to terms with it, and would often mention their feelings of betrayal during the interviews (He has two children with another girl. It is hard for me that he had these children, while he was still with me). They then also had to deal with the harsh reality of domestic violence. Two of the participants $(10 \%)$ who were separated from their partners indicated that unfaithfulness and not the physical abuse was the main reason they had left their partners. Infidelity is also mentioned by Flinck et al. (2004:386) as a problem experienced by participants in their study. 


\section{- Sexual abuse}

Sexual abuse occurs when the perpetrator demands sexual activity without the woman's consent. It is also referred to as marital rape, whereby the male assumes that it is his right and privilege to have sex whenever he wishes and in any form he desires, without taking his female partner's feelings into consideration (Domestic Violence Act, No. 116 of 1998; Wiehe, 1998:6). Stereotyped sex roles might lead to an increase in sexual abuse. Some women do not realise that they also have rights, and will do everything their partners demand of them, just because they feel it is the right thing to do. Women often are not even aware that they are sexually abused. Several studies have indicated women's discomfort regarding certain sexual acts expected by their partners, while continuing to comply with these behaviours, because they see it as an obligation towards their partners (Bollen et al., 1999:21; Chapleau, Oswald \& Russel, 2007:131; Parenzee $\&$ Smythe, 2003:23).

According to Laird (2001:286), sexual abuse is often reinforced by an unspoken code of silence. Some women are just not in a position to talk about their sexual abuse due to shame, guilt and the fear that their families might disintegrate. Views by Bollen et al. (1999:25) support this code of silence, stating that, of all four types of abuse, sexual abuse is the least reported, the reason for this code of silence being the social stigma attached to sexual abuse.

Four of the 20 participants (20\%) in this study indicated that they were sexually abused by their partners. The sexual abuse ranged from being referred to as sexual objects $(\mathrm{He}$ treats me like a sexual object), being forced to wear "sexy" clothes ("I also had to wear clothes that I did not want to wear ... you know ... exposing ones"), and having certain sexual behaviours enforced while the male partners were under the influence of substance abuse ("It is like that that he sometimes forces me to have sex if he is under the influence of drugs") to rape ("He has already raped me"). This correlates with findings by Flinck et al. (2004:387), in which sexual abuse was described as treating women as sexual objects, intercourse by coercion, undressing the victim, demands relating to clothing, derogatory name-calling, and inflicting pain. Authors such as Bollen et al. (1999:23), Haj-Yahia (2000:237), Nam (2002:241) and Postmus and Hahn (2007:475) indicate that sexual abuse often is a sensitive, taboo topic among certain cultures, while Vincent and Jouriles (2002:87) found that 43 of 97 women who were physically abused (44\%) also indicated that they were being sexually assaulted by their partners.

\section{- Economic abuse}

This type of abuse implies the withholding of economic support and keeping tight control over the family's economic resources, such as money and transport. The false perception often is that the woman in the relationship is solely responsible for all the housekeeping and child-rearing tasks with the minimum financial assistance, and that she must also work a full day to provide for the family's financial needs.

In their research, Davhana-Maselesele, Myburg and Poggenpoel (2009:2517) found that some women could not do anything without their partners' approval. Even if they had 
money, they could not buy what they wanted to buy and had to get their partners' approval for any financial decisions. Some abused women do not have control over their money, as their partners control all the finances. It was also found that some abused women who worked had to hand over their salaries to their partners. This money would often be misused and no money would be available for necessities such as school and taxi fees. Some perpetrators would also exert financial control by denying their partners access to bank accounts or credit cards. Pyles (2006:69) is of the opinion that some lowincome women may want to seek employment to improve their financial situation, but are prevented by their controlling partners.

Half of the participants $(50 \%)$ in this study indicated that their partners failed to provide financially for their families. Five of these participants (25\%), stated that their partners would deliberately withhold money for necessary household items and some would spend it on alcohol or drugs. Comments from participants about economic abuse included:

"He said I just want his money ... he never gives me enough money for food."

"He does not pay a cent towards the education of the children."

"... and I could not get out of the situation. Who is going to pay for the house, who is going to look after the children? What about the medical aid? Financially he did not do his part. He drank away all our money and we lost the house. I was like a prisoner and he had the keys."

These statements reflect that economic abuse varies from irresponsible behaviour such as squandering money on chemical substances to refusing to contribute financially to the living expenses. There often is a false perception that women are solely responsible for the housekeeping, child-rearing and have to be the breadwinner, which exposes them to economic abuse (Wiehe, 1998:6). Flinck et al. (2005:384) found that all seven participants in their study were exposed to some or other form of economic abuse and this study echoes their findings. Jewkes et al. (2002:1603) are of the opinion that women who are battered by their intimate partners, often also have to deal with economic abuse.

Chronister (2007:706) and Pyles (2006:65) have indicated that low-income women, who are exposed to economic abuse face huge challenges in making a living for themselves and their children.

\section{- All four types of abuse}

The discussion now focuses on situations where all types of domestic violence were present. A number of women who are physically abused are also abused emotionally. Various scholars (Leiner, Compton, Houry \& Kaslow, 2008:473; Pineless, Mineka \& Zinbarg, 2008:166; Scott-Tilley; Stephens \& McDonald, 2002:78) are of the opinion that psychological aggression is a frequent precursor of physical aggression. Economic abuse and sexual abuse often go hand in hand with physical abuse and emotional abuse, but are not mentioned as frequently by abused women. Parenzee and Smythe (2003:21-25) have observed that a lack of knowledge of the different types of abuse may be a possible 
reason for not mentioning these two types of abuse. The following quotes illustrate the presence of all four types of abuse:

"He went on the whole evening. He kicked me and he shouted at me and called me names throughout the night. We could not sleep. He also does not give me money to buy food for the kids.... He then started to beat me and, how could I say, also abused me sexually."

"He beat me and kicked me and abused me severely...because I could not do it on my own, as he never gave me money... but the words ... they remain. He also raped me..."

"He calls me names and then beats me, not in the face so that the people can see, but on my body ... with a stick or a belt or a broom ... Then he also gives money to his girlfriend, but not to me for food ... he also forces me to wear these exposing clothes which I don't like."

Four of the participants (20\%) indicated that they were exposed to all four types of domestic violence, as is evident from the excerpts. Different authors (Bollen et al., 1999:8; Bassuk et al., 2005:387; Griggs et al., 2005:68; Wiehe, 1998:6) agree that all four types of domestic violence often occur simultaneously and Vincent and Jouriles (2002:78) conclude that the well-being of many women is negatively affected by their partners who use different types of domestic violence. Davis (2001:33) argues that social workers should be trained to identify the different types of domestic violence and to deal with this complex issue.

\section{IMPLICATIONS FOR PRACTICE}

All the participants in the study had been physically abused. At least five of the twenty participants (25\%) indicated that they were exposed to "patriarchal terrorism", in being physically abused at least once (sometimes up to three times) a week. All the participants had also been exposed to emotional abuse. Most of them indicated that they experienced the emotional abuse as worse than the physical abuse. Twenty percent of the participants revealed that they experienced sexual abuse and half of them indicated that they were abused emotionally. Twenty percent of the participants indicated that they were exposed to all four types of abuse.

These findings have the following implications for practice.

- For casework:

- Social workers should identify and assess the different types of domestic violence. Physical abuse could also include physical neglect, as discussed. The range of physical abuse should be noted and "milder" types of domestic violence should also be seen as a serious matter, as it could lead to serious emotional implications for abused women and their families.

- Social workers should assist women who have been emotionally abused to deal with the severe consequences of emotional abuse by means of drawing up an assessment and intervention plan. Empowering women should form part of 
intervention. Unfaithfulness is part of emotional abuse and should be treated accordingly.

- Social workers should handle women who have been sexually abused by their partners with great sensitivity, because they have to live with the stigma attached to sexual abuse. The right of women not to comply with the type of sexual behaviour that makes them feel uncomfortable should also be addressed by social workers.

- Social workers should educate women on economic abuse. Misuse of well-earned money or financial control by partners should be discouraged and women should be empowered to also have a say in financial matters and the running of the household. These aspects could be addressed in an intervention plan.

- Group work could be used very meaningfully as a social work method to address domestic violence. In group work, abused women could benefit through realising that they are not alone in facing their challenges. Abused women could share their experiences and their methods of dealing with the different types of domestic violence during group work. Social workers could thus use group work as a method to facilitate a process whereby abused women can support one another. Educational groups could also help abused women to gain more insight into relevant matters and how to deal with aspects such as legal matters; the intervention of the police; the role of the social worker; and how to draw up a safety plan to, mention but a few.

- Community work as a social work method could be used to create awareness of the devastating effect domestic violence has on women, children, families, communities and society. A whole range of role players could assist in creating this awareness, for instance churches, the police, schools, community leaders and different welfare organisations. Shelters for abused women and their children could also offer community work projects to help women in the shelter to resettle in the community again after their stay in the shelter. Aspects such as employment and how to live without the abusive partner could form part of the sustainability of community projects.

- Further research on domestic violence should be undertaken to gain greater insight into how to break this cycle of violence. The different types of domestic violence and how women experience it could be explored in further research. Other issues regarding domestic violence that could be researched may involve the profile of the abused woman; the profile of the perpetrator; the effect of domestic violence on children; and the role of the police. Research on domestic violence should be viewed as a high priority to attempt to break the cycle of domestic violence.

\section{BIBLIOGRAPHY}

AMOAKOHENE, M.I. 2004. Violence against women in Ghana: a look at women's perceptions and review of policy and social responses. Social Science and Medicine, 59(11):2373-2385. 
ARTZ, L.M. 1999. Violence against women in rural Southern Cape: exploring access to justice within a feminist jurisprudence framework. Cape Town: University of Cape Town, Department of Criminology. (MA Thesis)

BASSUK, E., DAWSON, R. \& HUNTINGTON, N. 2005. Intimate partner violence in extremely poor women: Longitudinal patterns and risk markers. Journal of Family Violence, 21(6):387-398.

BOLLEN, S., ARTZ, L.M., VETTEN, L. \& LOUW, A. 1999. Violence against women in metropolitan South Africa: a study on impact and service delivery. ISS Monograph Series No 41, Sept.

BROWNE, K. \& HERBERT, M. 1997. Preventing family violence. New York, Chichester: John Wiley and Sons.

CALLAGHAN, J.E.M. 1995. Women's experiences of violence in intimate relationships. Durban: University of Natal, Department Psychology. (MA Thesis)

CARLSON, B. 1991. Domestic violence. In: GITTERMAN, A. Handbook of Social Work Practice with vulnerable populations. New York: Columbia University Press.

CARSTENS, S. 2007. Regsman, sosiale werker lig gesinskwessies saam toe. Rapport, 12.02.2007.

CHAPLEAU, K.M., OSWALD, D.L. \& RUSSEL, B.L. 2007. How ambivalent sexism toward women and men supports rape myth acceptance. Sex Roles, 57:131-136.

CHRONISTER, K.M. 2007. Contextualising women domestic violence survivors' economic and emotional dependencies. American Psychologist, 62(7):706-708.

CRESWELL, J.W. 2003. Research design. Qualitative, quantitative and mixed methods approaches $\left(2^{\text {nd }}\right.$ ed). London: Sage Publications.

DAMON, F.E. 2003. Factors underlying women's decision not to report physical abuse: a qualitative exploration. Stellenbosch: University Stellenbosch, Department Sociology. (MA Thesis)

DANIS, F.S. \& LEE, J. 2003. The criminalization of domestic violence: what social workers need to know. Social Work Journal of the National Association of Social Work, 48(2)145-288.

DANIS, F.S. \& LOCKHEART, L. 2004. Breaking the silence in social work education. Domestic violence modules for foundation courses. Alexandria: Council of Social Work Education.

DAVHANA-MASELESELE, M., MYBURGH, C.P.H. \& POGGENPOEL, M. 2009. Lived experiences of women victims of domestic violence in rural areas of Vhembe district: Limpopo Province, South Africa. Gender and Behaviour, 7(2):2517-2540.

DAVIS, L.V. 2001. Why do we still need a women's agenda for Social Work? In: PETERSON, K.J. \& LEIBERMANN, A.A. Building on women's strengths. New York, London, Oxford: The Haworth Press, Inc. 
DE VOS, A.S., STRYDOM, H., FOUCHÉ, C.B. \& DELPORT, C.S.L. Research at grassroots: for the social sciences and human service professions $\left(4^{\text {th }}\right.$ ed $)$. Pretoria: Van Schaik Publishers.

DWYER, D.C., SMOKOWSKI, P.R., BRICOUT, J.C. \& WODARSKI, J.S. 1995. Domestic violence research: Theoretical and practical implications for Social Work. Clinical Social Work Journal, 23(2):185-198.

ENOSH, G. \& BUCHBINDER, E. 2005. Strategies of distancing from emotional experience-making memories of domestic violence. Qualitative Social Work, 4(1):932.

FERRATO, D. 2000. Living with the enemy. New York: Aperture Foundation.

FLEURY-STEINER, R.E., BYBEE, D., SULLIVAN, C.M., BELKNAP, J. \& MELTON, H.C. 2006. Contextual factors impacting battered women's intentions to reuse the criminal legal system. Journal of Community Psychology, 34(3):327-342.

FLINCK, A., PAAVILAINEN, E. \& ASREDT-KURKI, P. 2005. Survival of intimate partner violence as experienced by women. Journal of Clinical Nursing, 14(3):383393.

FOUCHÉ, C.B. \& DE VOS, A.S., 2011. Formal formulations. In: DE VOS, A.S., STRYDOM, H., FOUCHÉ, C.B. \& DELPORT, C.S.L. Research at grassroots: for the social sciences and human service professions $\left(4^{\text {th }} \mathrm{ed}\right)$. Pretoria: Van Schaik Publishers.

FOUCHÉ, C.B. \& SCHURINK, W. 2011. Qualitative research designs. In: DE VOS, A.S., STRYDOM, H., FOUCHÉ, C.B. \& DELPORT, C.S.L. Research at grassroots: for the social sciences and human service professions $\left(4^{\text {th }}\right.$ ed). Pretoria: Van Schaik Publishers.

GELLES, R.J. 1999. Family violence. In: HAMPTON, R.L. Family violence: prevention and treatment $\left(2^{\text {nd }}\right.$ ed). London: Sage Publications.

GRIGGS, R., MORRIS, R. \& EHLERS, R. 2005. Preventing the victimisation of women and children. A review of six South African programmes. Newlands: Open Society Foundation of South Africa.

HAJ-YAHIA, M.M. 2000. Wife battering in the socio-cultural context of Arab society. Family Process, 39(2):237-255.

HAMPTON, R.L., VANDERGRIFF-AVERY, M. \& KIM, J. 1999. Understanding the origins and incidence of spousal violence in North America. In: GULLOTTA, T.P. \& McELHANEY, S.J. Violence in homes and communities. Prevention, intervention and treatment. (Vol. 11). Issues in children's and families' life. Thousand Oaks, London, New Delhi: Sage Publications.

HARRISON, J. 1998. The experiences of women in marriages characterised by domestic violence and substance abuse. Johannesburg: University of the Witwatersrand, Department of Psychology. (Unpublished MA Thesis) 
HENNING, E. 2004. Find your way in qualitative research. Pretoria: Van Schaik Publishers.

JEWKES, R., LEVIN, J. \& PENN-KEKANA, L. 2002. Risk factors for domestic violence: findings from a South African cross-sectional study. Social Science Medicine, 55(9):1603-1617.

LAIRD, J. 2001. Changing women's narrative: taking back the discourse. In: PETERSON, K.J. \& LEIBERMANN, A.A. Building on women's strengths. New York, London, Oxford: The Haworth Press, Inc.

LEINER, A.S., COMPTON, M.T., HOURY, D. \& KASLOW, N.J. 2008. Intimate partner violence, psychological distress, and suicidality: a path model using data from African American women seeking care in an Urban Emergency Department. Journal of Family Violence, 23(1):473-481.

LUDSIN, H. \& VETTEN, L. 2005. Spiral of entrapment. Abused women in conflict with the law. Johannesburg: Jacana Media.

MAKOFANE, M.D.M. 2002. Factors compelling women to remain in abusive relationships. Acta Criminologica, 15(1)84-92.

NAM, Y. 2002. Partner abuse and welfare receipt among African-American and Latin women living in a low-income neighbourhood. Social Work Research, 26(4):241-251.

NORDIEN, R. 2003. Muslim women's experiences of domestic violence in the Nelson Mandela Metropole. Port Elizabeth: University of Port Elizabeth, Department of Social Work. (MA Thesis)

PARENZEE, P. \& SMYTHE, D. 2003. Domestic violence \& development: looking at the farming context. University of Cape Town, Institute of Criminology.

PINELESS, S.L., MINEKA, S. \& ZINBARG, R. 2008. Feedback-seeking and depression in survivors of domestic violence. Depression and Anxiety, 27(3):166-172.

POSTMUS, J.L. \& HAHN, S.A. 2007. The collaboration between welfare and advocacy organisations: learning from the experiences of domestic violence survivors. Families in Society, 88(3):475-484.

PURVIN, D.M. 2007. At the crossroads and in the crosshairs: Social Welfare Policy and low-income women's vulnerability to domestic violence. Social Problems, 54(2):188210.

PYLES, L. \& KIM, K.M. 2006 A multilevel approach to cultural competence: a study of the community response to domestic violence victims. Social Work Abstracts, 24(3):87-95.

REPUBLIC OF SOUTH AFRICA (RSA) Government Gazette. 1998. No. 116 of 1998: Domestic Violence Act, 19537. Johannesburg: Government Printers.

RIGER, S., BENNET, L., WASCO, S.M., SCHEWE, P.A., FROHMANN, L., CAMACHO, J.M. \& CAMPBELL, R. 2002. Evaluating services for survivors of domestic violence and sexual assault. London: Sage Publications. 
ROCHE, S.E. 1999. Using a strengths perspective for social work practice with abused women. Journal of Family Social Work, 3(2):23-37.

ROMITO, P. 2008. A deafening silence. Hidden violence against women and children. Bristol, Great Britain: The Policy Press.

RUIZ-PEREZ, I. \& MATA-PARIENTE, N. 2006. Women's response to intimate partner violence. Sociological Abstracts, 21(9):1156-1168.

SANDERSON, C. 2008. Counselling survivors of domestic abuse. London and Philadelphia: Jessica Kingsley Publishers.

SCOTT-TILlEY, D., TILTON, A. \& SANDEL, M. 2010. Biologic correlates to the development of post-traumatic stress disorder in female victims of intimate partner violence: Implications for practice. Perspectives in Psychiatric Care, 46(1):26-37.

STEPHENS, N. \& MCDONALD, R. 2002. Assessment of women who seek shelter from abusing partners. In: VINCENT, J.P. \& JURILES, E.N. Domestic violence. Guidelines for research-informed practice. Philadelphia: Jessica Kingsley Publishers.

STRYDOM, H. \& DELPORT, C.S.L. 2011. Sampling and pilot study in qualitative research. In: DE VOS, A.S., STRYDOM, H., FOUCHÉ, C.B. \& DELPORT, C.S.L. Research at grassroots: for the social sciences and human service professions $\left(4^{\text {th }}\right.$ ed). Pretoria: Van Schaik Publishers.

SULLIVAN, M. \& HAGEN, L.A. 2005. Survivors' opinion about mandatory reporting of domestic violence and sexual assault by medical professionals. Affilia Journal of Women and Social Work, 20(3):346-361.

VINCENT, E.N. \& JURILES, J.P. 2002. Domestic violence. Guidelines for researchinformed practice. Philadelphia: Jessica Kingsley Publishers.

WALKER, L.E. 1984. The battered woman syndrome. New York: Springer.

WHITTAKER, A. 2009. Research skills for Social Work. Great Britain: Learning Matters, Ltd.

WIEHE, V.R. 1998. Understanding family violence. Treating and preventing partner, child, sibling and elder abuse. Thousand Oaks, London, New Delhi: Sage Publications.

Dr Ilze Slabbert, Prof Sulina Green, Department of Social Work, University of Stellenbosch, Stellenbosch, South Africa. 